DOI: 10.21005/pif.2021.47.C-01

\title{
THE IDENTITY IMPORTANCE IN SHAPING SELECTED, NEW URBAN SPACES IN WARSAW, PRAGA - PÓKNOC
}

\section{ZNACZENIE TOŻSAMOŚCI W KSZTAŁTOWANIU WYBRANYCH, NOWYCH PRZESTRZENI MIEJSKICH NA PRADZE - PÓŁNOC W WARSZAWIE}

\section{Ewa Jarecka - Bidzińska}

Ph.D. Eng. Architect,

Orcid: 0000-0002-1289-9784

\section{Małgorzata Denis}

Ph.D. Eng. Architect,

Orcid: 0000-0002-4694-116X

Warsaw University of Technology

Faculty of Geodesy and Cartography

Department of Spatial Management and Environmental Sciences

\begin{abstract}
The article analyzes how selected important public places in Praga-Północ have developed throughout history and how, in the face of today's economic, functional and spatial conditions as well as socio-cultural needs, create inclusive, resident-friendly urban spaces that build a positive image of the district. The authors will attempt to present proposal for system of interconnected public spaces based on the potential of the place.. The model of connections, the proposed system of urban spaces in Praga - Północ is based on many years of researches in situ.
\end{abstract}

Key words: public space, Praga - Północ, local identity.

\section{STRESZCZENIE}

W artykule przeanalizowano, jak kształtowały się wybrane ważne miejsca publiczne Pragi - Północ na przestrzeni dziejów oraz jak w obliczu dzisiejszych uwarunkowań gospodarczych, funkcjonalno przestrzennych i potrzeb społeczno - kulturowych, stworzyć integrujące, przyjazne mieszkańcom oraz budujące pozytywny wizerunek dzielnicy przestrzenie miejskie. Podjęto próbę przedstawienia propozycji systemu powiązań przestrzeni publicznych w oparciu o potencjał miejsca. Model powiązań, zaproponowany system przestrzeni miejskich na warszawskiej Pradze - Północ jest oparty na wieloletnich badaniach in situ.

Słowa kluczowe: przestrzeń publiczna, Praga - Północ, tożsamość lokalna. 


\section{INTRODUCTION - THE AIM OF STUDY}

The aim of the article is the case study of places with strong identity and potential to build attractive public spaces: Praga Port (Previous river harbor, current commercial investment on land of 50ha), place between Nove Kino Praha (cinema) and Tax Office, Centrum Praskie Koneser (former industry complex, adapted to commercial functions), Fort Śliwickiego (currently abandoned) and next to Warszawa Stadion Narodowy Railway Station. The aim of the research is to describe identity importance in shaping selected, new urban spaces in Praga - Północ and present selected examples with the system of connections between public spaces. Besides approximation characteristics, significance and status of the most important places in Prague including the factors discussed in the section methods. The author using data obtained from questionnaires made in 05.2018, also defines the areas that have the potential to create new public spaces. According to J. Ghel (Ghel J.,1987, p17) The presence of other people, activists, events, inspiration and stimulation comprise one of the most important qualities of public spaces altogether.

\subsection{Research methods}

1) Empirical - searching, studying literature - criticism as scientific discourse;

2) Analysis of plans, cartographic, descriptive, documentary sources;

3) Method intuitive - the definition of general scientific problems;

4) Observation method;

5) Case study;

6) Photographic documentation analysis;

7) Interviews, questionnaires (05.2018): experts, district authorities, inhabitants.

The author has analyzed the literature on the subject and began its scientific discourse. The conclusions from the literature analysis are described in following chapters. Selected, most important, current public spaces and places with potential were analyzed. The author examined the following factors: social, history, culture, heritage, functionality, development, location, public utility, greenery, modernity or architecture. There were conducted many years of study sites observations the at different seasons, daytime and circumstances. The photographic documentation was made with over 300 photographs depicting different places, surrounding architecture, way of development and public space's way of use. A selection of specific areas of attractive public spaces and those requiring revitalization was made. The author has made questionnaires among district authorities, experts, officials, local activists and residents regarding relationship issues of the identity and shaping public spaces in Praga - Północ, devised for the purposes of a survey or statistical study. Conducted research and interviews were summarized in diagrams and tables

\section{PLACE IDENTITY OF PRAGA PÓŁNOC}

The Genius loci of Prague is defined by unique character, authentic urban tissue structure, order, composition and spatial relations (Burdzik T, 2012; Jarecka - Bidzińska E., 2016; Norberg- Schulz Ch, 198), historical architecture, centuries-old traditional market, rich history, close proximity to the Old Town, good public transportation with connections to the downtown, natural greenery reserve on bank of Vistula river, rich services offer, artistic neighborhood, multicultural character, the Praga's community - as separate environment with own dialect, lower time pace - that create unique atmosphere of a place, that attracts artistic environment, investors and tourists. The identity of Warsaw's Praga is extremely complex and variable over centuries, as its history. (E. Jarecka Bidzińska, 2017)

The first mention of Prague in literature describes self-developing trade village in the shape of spindle from 1432. At that time, Warsaw was not the capital, but it gained logistical importance, being at the crossroads of communication routes and a meeting place for the Seym of the Crown of the Kingdom of Poland and later the Seym of the Polish-Lithuanian Commonwealth Praca zbiorowa, 2006. At that time Praga was "functional foreground" of Warsaw, in which the nobles from eastern territories could rest before entering Warsaw. In 1648, Praga received city rights from 
King Władysław IV and became a city with privilege of setting up craft and merchant guilds. The city was also developing because there were pilgrimage routes to shrine of Loreto Lady located in Praga. The 18th century was the period of Prague's splendor - economic development, magnate and gentry possessions (Sołtan A, 1998, s.15-41, Kosim I. i J.,1876).

Prague formally became part of the capital and ceased to be an independent city in 1791 . The Kościuszko Insurrection ended several decades of Prague's economic development. "Praga's Carnage" in 1794 destroyed the district, where half of inhabitants were murdered. Then in 1807-1811, Napoleon Bonaparte, preparing for a war with Russia, ordered to demolish buildings to make place for fortifications. The historic downtown of Prague resembled village with ruined churches, cemeteries and manors. In subsequent years, attempts were made to introduce development and repair plans, but only partially implemented (pod redakcją Sołtan A, 2009).

The battles at fields of Białołęka and Olszynka Grochowska deterred the population from settling in Prague. A large part of the buildings of the district were wooden, what caused fires and degradation. Crime and poverty grew and district gained bad reputation. Prague after this period remained neglected suburb of the developing Warsaw. The period up to the nineteenth century was constant rebuilding of destruction. The second half of the nineteenth century was industry revolution first railway stations, lines and first permanent bridge after 261 years. Later significant damage were caused by evacuation of Russian troops after World War I, the German occupation and stationing of forces after the War( Elsztain P, 2002).

In the interwar period, development of Prague and the reconstruction of industry took place. There were also new public investments under the presidency of S. Starzyński. The destruction of World War II affected Praga much less than the left-bank districts of Warsaw. The social structure of Prague has changed because of Holocaust. Until the 1990s, Praga Północ was perceived as a place of I industry location and onerous services, a dangerous district, inhabited by a social margin. Today, Prague has become a functional part of city center.

\section{EXISTING, HISTORICAL PUBLIC SPACES, A REFERENCE TO HISTORY AND MEANING OF PUBLIC SPACES IN POLICY OF THE RUSSIAN EMPIRE}

There are three current, main, historical public spaces in Warsaw's Praga - Północ: Bazar Różyckiego, Plac Wileński, Plac Weteranów 1863. J. Ghel (Ghel J., Gemzoe, 2001, p10) describes traditional public spaces as follows: public space has always been served as meeting place, marketplace and traffic space. Bazar Różyckiego is traditional open-air market with centries old history. It was not only place of trade but also social meetings and even local illegal businesses. Bazar Różyckiego had "golden age" in Soviet regime time because it was the only place with full offer of goods to sell and most popular shoping place in all Warsaw. Bazaar was established in 1901 and operates today, although his popularity has fallen since the opening of the large-Vilnius Railway Station shopping center. The creation of a marketplace adjacent to Targowa Street, which previously served this function, enabled the beginning of the twentieth century to organize trade, development and the creation of boulevards that do not exist today on the main street of Prague (fig. 2). Rożycki Bazaar's buildings for over 100 years have kept their provisional character of wooden stalls and one-story pavilions in poor technical condition. For many years, the place was the "heart" of Prague, one of its symbols and the "house" of local folklore (Sidorek D, 2009 pp.106-130; Sujecki J., 2004). There are two new, important cultural institutions next to market place Centrum Kreatywności (business incubator for designers and artists) and Museum of Warsaw Praga. Unfortunately, the current development is temporary, and the homogeneous development is made in the form of container pavilions with no architectural details. Public opinion is rather negative, and the character itself, due to the large paved surface and architectural style, is called "concretecontainer" (Wojtczuk, 2021).

Vilnius Square (Plac Wileński) and Veterans Square 1863 (Plac Weteranów 1863r.) are related to the image of Russification policy. At the beginning of the 19th century, the concepts of Prague urban planning were made, as evidence of Prague's importance during the Kingdom of Congress, including the first comprehensive urban design of Prague - Jakub Kubicki's plan (1817). This plan, 
as well as its later versions, have not been implemented. They envisaged a compositional connection with the Royal Castle, seven radiant avenues, representative squares with public utility buildings, marketplaces, warehouses, industrial squares, parking yards and barracks. In 1823 new street lines have been marked out with the names of the reigning princes of Moscow: Alexander, Mikolaj, Konstantyn and Michał. The central point of Prague was designed as the square on the axis of new bridge and Aleksandryjska street, now partially preserved as the Veterans Square of 1863. Tsar wanted to create his administration center in Prague. For this purpose, he approved a new project for the regulation of Prague in 1835. Garrison, railway stations and the railway network were in Prague, what gave the possibility of decisive warfare and a smooth connection with the Russian Empire. For the Orthodox minority an Orthodox church of St. Maria Magdalena Equal to the Apostles, was erected. The Wilenski Square is located next to this temple near the Vilnius Station, formerly the St. Petersburg Railway Station.

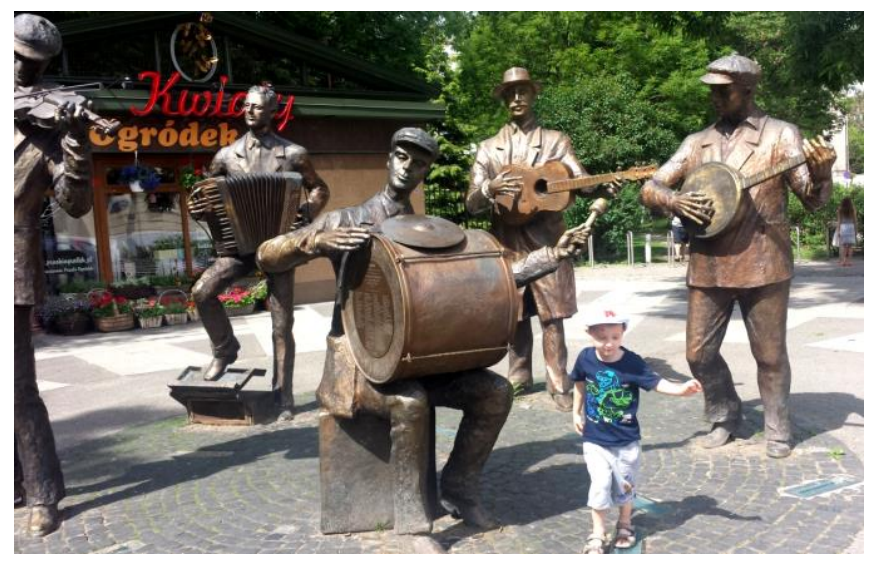

Fig. 1 View of Floriańska Street, statue of the Prague Band, Praga - Północ. Source: photo E. Jarecka - Bidzińska,, 2016

Ryc. 1. Przykład grupowania dwóch ilustracji obok siebie na stronie. Źródło: fot. E. Jarecka - Bidzińska,, 2016

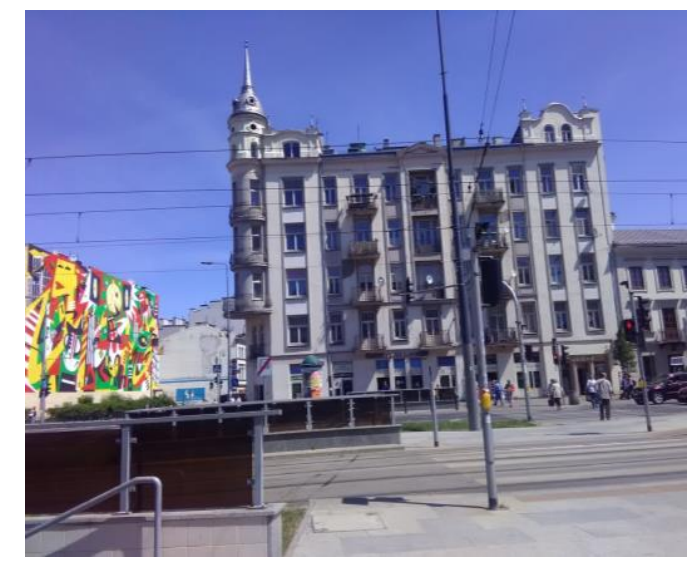

Fig. 2. Crossroad of Ząbkowska and Targowa Streets, next to Bazar Różyckiego. Source:photo E. Jarecka - Bidzińska, 2017

Ryc. 2. Ryc. 5. Skrzyżowanie ulic Zabkowskiej i Targowej przy Bazarze Różyckiego. Źródło: fot. E. Jarecka - Bidzińska, 2017

\section{SELECTION CRITERIA AND CASE STUDY OF PLACES WITH POTENTIAL IN PRAGA - PÓŁNOC}

According M. Happach i K. Sadowy ((Happach M., Sadowy K., 2014, s.9-20) Praga Center has a great and ready to run spatial development potential in the form of a streets network and historically stratified building. The advantage is city-owned properties, land, buildings and services in a diverse condition, what gives a chance to control effectively spatial transformations.

Praga - Północ needs a clear system of spatial spaces, which is presented in attached Fig.3. Over $75 \%$ of respondents voted for the creation of a readable model of public spaces in Praga - Północ (fig. 4,5). This article develops this idea with study case of several most potential, future public spaces on Praga - Północ and their relationship with identity importance. There are some current historical public spaces, some modern and some places with potential as Tab. 1 presents. Clear spatial and functional relations will shape the harmonious landscape of the district, support identity and heritage, positively influence on social and economic development.

According to J. Ghel (Ghel J.,1987, p.51) Public spaces are needed. The need for all spaces of all types and all sizes is obvious - from the little residential street to the city square. Author has chosen variety of public spaces to compare: future Port boulevards, adapted courtyard of Former Alcohol Rectification Plants Complex with historical, neogothic monuments, Natura 2000 land sur- 
rounded greenery and courtyard of former Fort adapted for National Museum purpose, Front yard of Stadium with recreation and sport function - most important public space with event function in Warsaw. In reference to the J. Jacobs (Jacobs J.,1961) theory Praga - Północ great value is mix of new with old, the poor with wealthy (...) this diversity is a good. It is particularly important to revitalization process to eliminate detrimental elements for the functioning of the area, but at the same time to preserved specific character, counteract gentrification and to prevent monuments from degradation (Bartoszewicz D., 2009).

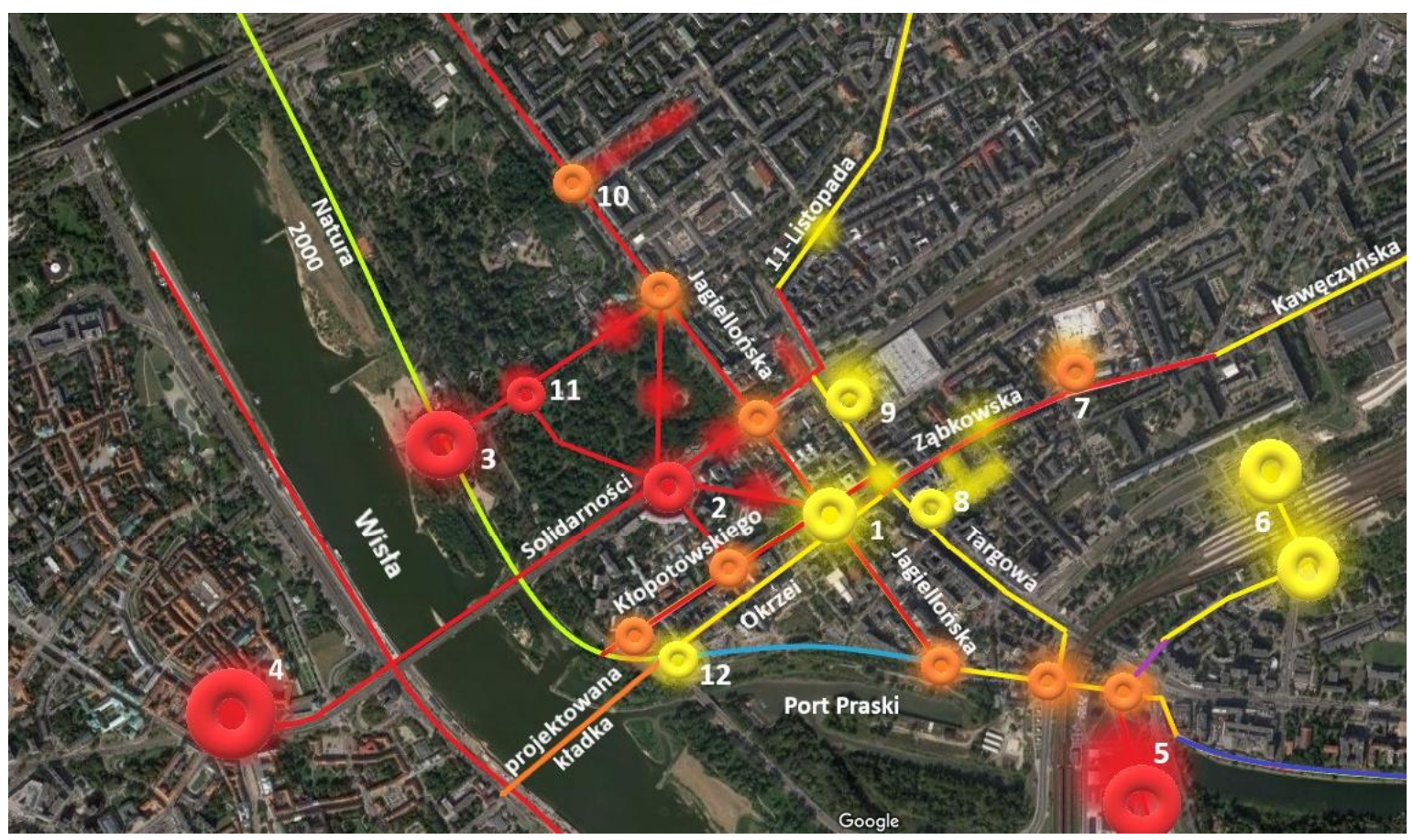

Fig. 3. Praga Północ and Old Town, Diagram of public spaces, nodal places and areas with potential. Red color means good public spaces, orange - attractive ones, requiring slight transformations, yellow - degraded, requiring revitalization, but with potential, illustration based on satellite photo Google maps. Source: E. Jarecka - Bidzińska,

Ryc.3 Praga Północ i Stare Miasto, Schemat przestrzeni publicznych, miejsc węzłowych i obszarów z potencjałem. Kolor czerwony oznacza dobre przestrzenie publiczne, pomarańczowy - atrakcyjne, wymagające niewielkich przekształceń, żółty zdegradowane, wymagające rewitalizacji, ale z potencjałem, ilustracja na podstawie zdjęć satelitarnych Google maps,źródło: E. Jarecka - Bidzińska,

Fig. 4. Results from questionnaires. Is Praga an original district? blue color - yes, red - no, orange - maybe. Source: author Ryc. 4. Wyniki $z$ ankiet. Czy Praga to oryginalna dzielnica?. Źródło: autor

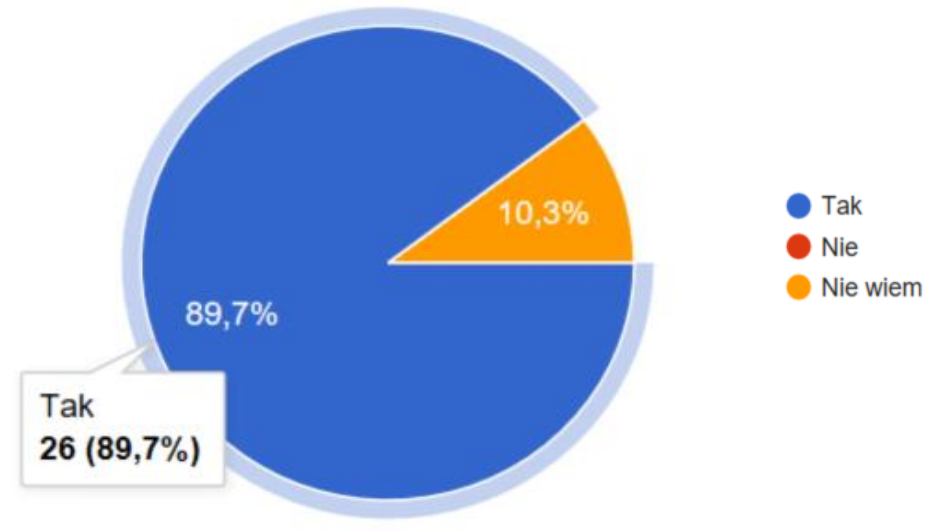


Fig. 5. Where is Praga's center? (single color different public space). Source: author

Ryc.5 Gdzie jest centrum Pragi? (jeden kolor - inna przestrzeń publiczna). Źródło: autor

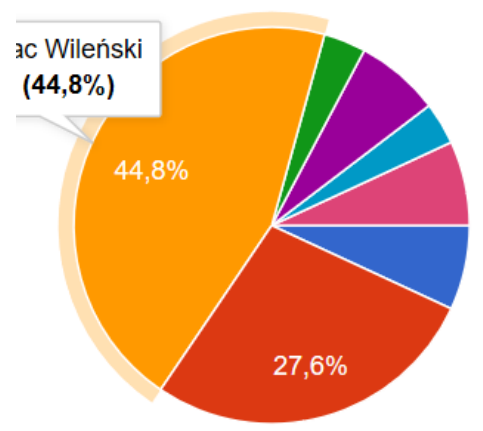

Bazar Różyckiego

Centrum Handlowe Warszawa Wileńska

Plac Wileński

Plac Weteranów 1863 Roku

ulica Ząbkowska na odcinku od ul. Targowej do ul. Brzeskiej

Plac Hallera

skrzyżowanie ulic Targowej i Ząbkowskiej

Tab. 1. Analisis of places with potential in Praga - Północ, Source: E. Jarecka - Bidzińska

Tab.1. Analiza miejsc z potencjałem na Pradze - Północ Źródło: autor: E. Jarecka - Bidzińska

\begin{tabular}{|c|c|c|c|c|c|}
\hline Criterion & Port Praski & $\begin{array}{c}\text { Centrum Praskie } \\
\text { Koneser }\end{array}$ & Fort Śliwickiego & $\begin{array}{l}\text { Square next to } \\
\text { National Stadium } \\
\text { Railway Station }\end{array}$ & $\begin{array}{l}\text { Square between } \\
\text { Nove Kino Praha } \\
\text { and Tax Office }\end{array}$ \\
\hline $\begin{array}{l}\text { The percentage } \\
\text { of respondents } \\
\text { voting for this } \\
\text { place as best } \\
\text { place to create } \\
\text { new public space }\end{array}$ & $\begin{array}{l}\text { Majority of } \\
\text { votes around } \\
50 \% \text { - first } \\
\text { place }\end{array}$ & Around $25 \%$ of votes & $\begin{array}{l}\text { Almost } 30 \% \text { of } \\
\text { votes - second } \\
\text { place }\end{array}$ & Over $25 \%$ of votes & Over $15 \%$ of votes \\
\hline $\begin{array}{l}\text { Territorial range, } \\
\text { location }\end{array}$ & regional & regional & regional & regional & local \\
\hline $\begin{array}{l}\text { History and cul- } \\
\text { tural heritage of } \\
\text { place }\end{array}$ & $\begin{array}{l}\text { Former river } \\
\text { harbor build in } \\
\text { interwar peri- } \\
\text { od, , no histor- } \\
\text { ical architec- } \\
\text { ture left }\end{array}$ & $\begin{array}{l}\text { Former Alcohol Recti- } \\
\text { fication Plants, closed } \\
\text { in } 2007 \text { year, new } \\
\text { and historical archi- } \\
\text { tecture, neogothic } \\
\text { monuments pre- } \\
\text { served, rich heritage }\end{array}$ & $\begin{array}{l}\text { Abandoned former } \\
\text { military fort, the } \\
\text { core of Warsaw } \\
\text { Fortress, was built } \\
\text { in } 1835-1836 \\
\text { waiting for adapta- } \\
\text { tion as part of } \\
\text { National Museum } \\
\text { complex, } \\
\end{array}$ & $\begin{array}{l}\text { New public space, } \\
\text { modern architec- } \\
\text { ture of National } \\
\text { Stadium, neigh- } \\
\text { borhood of Park } \\
\text { Skaryszewski }\end{array}$ & $\begin{array}{c}\text { Historical and mod- } \\
\text { ern builngs around } \\
\text { (Nove Kino Praha, } \\
\text { Tax Office) }\end{array}$ \\
\hline $\begin{array}{l}\text { Economic impor- } \\
\text { tance }\end{array}$ & $\begin{array}{l}\text { Commercial } \\
\text { investment - } \\
\text { very high } \\
\end{array}$ & $\begin{array}{l}\text { Commercial invest- } \\
\text { ment - high }\end{array}$ & $\begin{array}{c}\text { Public investment } \\
\text { of a high rank - } \\
\text { very high }\end{array}$ & $\begin{array}{l}\text { Possible public- } \\
\text { private partnership } \\
\text { investment - high }\end{array}$ & $\begin{array}{l}\text { Possible public } \\
\text { investment - low }\end{array}$ \\
\hline $\begin{array}{l}\text { Potential to create } \\
\text { workplaces }\end{array}$ & highest & high & high & low & low \\
\hline $\begin{array}{l}\text { Additional bene- } \\
\text { fits from creating } \\
\text { new public space }\end{array}$ & $\begin{array}{l}\text { Brown field } \\
\text { revitalisation }\end{array}$ & $\begin{array}{l}\text { Brown field revitalisa- } \\
\text { tion }\end{array}$ & $\begin{array}{l}\text { Economic devel- } \\
\text { opment of district, } \\
\text { building the Praga } \\
\text { - Północ image, } \\
\text { support for the } \\
\text { science sector } \\
\text { related to nature } \\
\text { conservation }\end{array}$ & $\begin{array}{l}\text { Creation of the } \\
\text { biggest and best } \\
\text { developed open - } \\
\text { air public space } \\
\text { with event function } \\
\text { in Warsaw }\end{array}$ & $\begin{array}{l}\text { Low budget revitali- } \\
\text { zation of very im- } \\
\text { portant public space } \\
\text { in Praga functional } \\
\text { centre }\end{array}$ \\
\hline $\begin{array}{l}\text { Possible urban } \\
\text { structure and type } \\
\text { of development }\end{array}$ & $\begin{array}{l}\text { Port boule- } \\
\text { vards can be } \\
\text { built there }\end{array}$ & $\begin{array}{l}\text { Adapted courtyard of } \\
\text { Former Alcohol Recti- } \\
\text { fication Plants Com- } \\
\text { plex }\end{array}$ & $\begin{array}{c}\text { Natura } 2000 \text { land } \\
\text { surrounded green- } \\
\text { ery and courtyard } \\
\text { of Fort }\end{array}$ & $\begin{array}{l}\text { Front yard of } \\
\text { Stadium with } \\
\text { recreation and } \\
\text { sport function and } \\
\text { small-scale archi- } \\
\text { tecture with basic } \\
\text { services. Open - } \\
\text { air space for } \\
\text { events. }\end{array}$ & $\begin{array}{l}\text { Attractive city } \\
\text { square with mix of } \\
\text { function and type of } \\
\text { building around. }\end{array}$ \\
\hline Current state & $\begin{array}{c}\text { Now commer- } \\
\text { cial invest- } \\
\text { ment on about } \\
50 \text { ha }\end{array}$ & $\begin{array}{c}\text { Now commercial } \\
\text { investment on about } \\
\text { 7ha, mixed residetial, } \\
\text { service and offices, }\end{array}$ & $\begin{array}{l}\text { Fort degraded } \\
\text { building is waiting } \\
\text { for adaptation as } \\
\text { part of National } \\
\text { Museum with }\end{array}$ & $\begin{array}{l}\text { New public space } \\
\text { next to National } \\
\text { Stadium and } \\
\text { railway station. } \\
\text { Empty place often }\end{array}$ & $\begin{array}{l}\text { Now it is place with } \\
\text { potential, current } \\
\text { function is parking } \\
\text { place and empty } \\
\text { square with no }\end{array}$ \\
\hline
\end{tabular}




\begin{tabular}{|c|c|c|c|c|c|}
\hline & & & $\begin{array}{c}\text { complex of new } \\
\text { buildings. }\end{array}$ & $\begin{array}{c}\text { use for public } \\
\text { events purpose. }\end{array}$ & $\begin{array}{l}\text { greenery, no small } \\
\text { architecture. }\end{array}$ \\
\hline Social importance & $\begin{array}{l}\text { Very high if } \\
\text { place will be } \\
\text { open for } \\
\text { public }\end{array}$ & $\begin{array}{l}\text { High if place will be } \\
\text { open for public }\end{array}$ & $\begin{array}{l}\text { High if place will be } \\
\text { open for public }\end{array}$ & $\begin{array}{c}\text { Very high if place } \\
\text { will be open for } \\
\text { public }\end{array}$ & $\begin{array}{l}\text { High if place will be } \\
\text { open for public }\end{array}$ \\
\hline $\begin{array}{l}\text { Greenery and } \\
\text { landscape poten- } \\
\text { tial of place }\end{array}$ & high level & low level & high level & high level & low level \\
\hline Opportunities & $\begin{array}{c}\text { Attractive } \\
\text { water land } \\
\text { development } \\
\text { with marina, } \\
\text { services and } \\
\text { shops }\end{array}$ & $\begin{array}{l}\text { Economic impulse for } \\
\text { degraded neighbor- } \\
\text { hood }\end{array}$ & $\begin{array}{l}\text { Economic impulse } \\
\text { for degraded for- } \\
\text { mer industry } \\
\text { neighborhood and } \\
\text { unpopular greenery } \\
\text { land }\end{array}$ & $\begin{array}{l}\text { Public space with } \\
\text { city and regional } \\
\text { scale importance }\end{array}$ & $\begin{array}{c}\text { Public space with a } \\
\text { potential to be need } \\
\text { Praga - Północ } \\
\text { functional and social } \\
\text { centre }\end{array}$ \\
\hline $\begin{array}{l}\text { Accessibility of } \\
\text { future public } \\
\text { space }\end{array}$ & good & good & low & very good & very good \\
\hline $\begin{array}{l}\text { Safety of future } \\
\text { public space }\end{array}$ & high & high & moderate & moderate & moderate \\
\hline $\begin{array}{l}\text { Diversity of future } \\
\text { public space }\end{array}$ & high & high & moderate & high & high \\
\hline
\end{tabular}

\section{SELECTED PLACES WITH POTENTIAL IN PRAGA - PÓŁNOC}

New public spaces create society but also activate great potential with revitalization of brown fields, that can solve part of economy and social problems in Praga - Północ. The basic problem is that these spaces should give the possibility of social integration, be a response to the needs of residents, pedestrian traffic should be privileged, the function and architecture should be diverse. To consider the validity of the above selection should be discussed carefully analyze existing, historic public spaces, their advantages and disadvantages. From existing public spaces discussed in the previous chapter, only the Veterans Square of 1863 is attractive. There is a church and a hospital that generate mass of people walking through square. There are: small architecture, benches, monuments, the neighborhood of historic architecture, greenery, original cobbled street and street lamps. At the square or in its immediate vicinity there are also: popular lunch bar, oriental restaurant, grocery store, passport office, photographer, small market and a hotel. All of this create character and conditions conducive to willing use of the square.

Wileński Square is always empty despite new pavement surface, location of subway entrance and greenery. Where is the problem? First of all, it is huge communication hub - nobody wants to spend time in its immediate vicinity. In addition, nearby Galeria Wileńska concentrates pedestrian traffic related with transportation and trade. Therefore, there is no direct access to small trade or gastronomy nearby. In addition, there are also properties closed for pedestrians: Building of Railway Directorate, Orthodox parish buildings and former administrative.

The new, yet non-existent public space that most respondents have chosen is Port Praski regional investment (fig.6). The whole area is about 50 ha, part of which is designated as reserve due to existing natural greenery, part of land for office buildings and part for services. Currently, the area in immediate vicinity of old river harbor is empty and waiting for construction. This will be preceded by construction of water gate protecting from the flood and regulating water level in future marina. There is no preserved architecture in harbor area. Project includes implementation of port promenade with services on ground floors and revitalization of brown fields (Denis M., 2020). However, 
it is a fully commercial investment, where diversity of architecture and functions may not meet all the needs of local residents. Near the river port is the surrounding of historical, nineteenth-century architecture of Old Praga, which survived the II World War and is testimony of times.

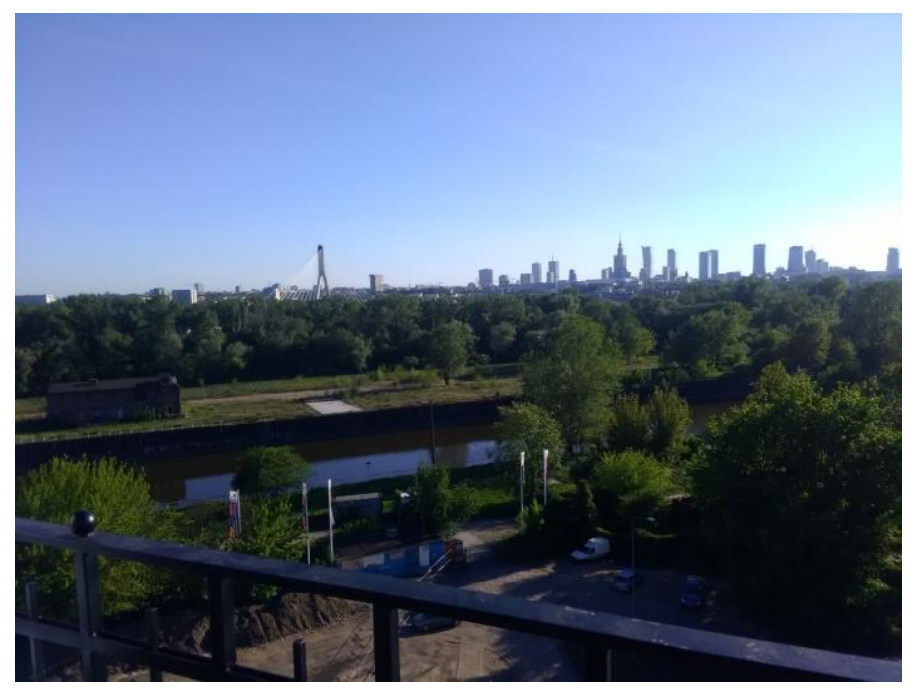

Fig. 6. Port Praski. Source: photo E. Jarecka Bidzińska, 2018

Ryc.6 Port Praski. Źródło: fot. E. Jarecka Bidzińska, 2018

Another space chosen in second place by respondents is the area of the former abandoned military Fort. It is an area selected by the local government of the commune for new investment the $\mathrm{Na}$ tional Museum of Nature in adapted historical buildings and complex of new architecture (fig.7). The whole area is adjacent to Natura 2000, green areas and a horse stable. There are new municipal settlements with high architectural value nearby and less aesthetic, high housing estates from the 80 's. The problem of this area is defragmentation of space, where modern residential buildings drastically disturb urbanism and introduce spatial disorder into historical buildings: fort, caponiers, barracks. In addition, it is an area with numerous urban barriers: railway line, embankment, Vistula river, multi-lane Jagiellońska artery, a huge transport hub - Rondo Starzyńskiego. The value is greenery, historical buildings and empty areas for investments. It would be revival of the unpopular area and creation of jobs within the public investment, which allows local goverment to control the level protection of the surrounding nature and proper adaptation of historic architecture during investment process.
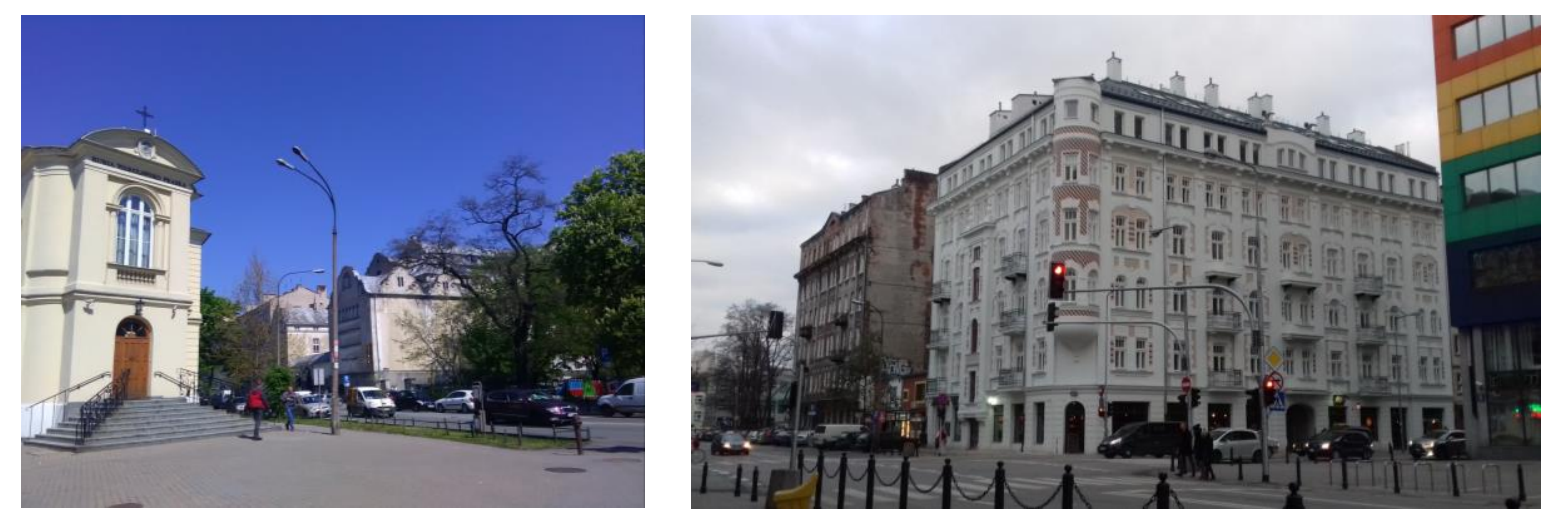

Fig. 7, 8. Potential public space from Fig.7 Source: photo E. Jarecka - Bidzińska,2018

Ryc. 7, 8. Przestrzeń publiczna z potencjałem - przedstawiona też na Ryc.7., źródło: fot. E. Jarecka - Bidzińska, 2018 
The last discussed place will be the area next to the Tax Office (fig. 8,9,10,). It is an existing square, which, with small financial expense,, could become new center of Praga. All that is needed is a different vehicular traffic organization or square with pedestrian access only. The place meets all requirements discussed by J. Jacobs: there is a variety of architecture, historical and contemporary buildings, mix of function (cinema, offices, cafes, shops, galleries, catholic institutions, other public institutions and private services) (Jacobs,J., 1961). There is also good communication with metro station nearby. The square is located in the heart of district and meeting place. Residents often sit on windowsills of the Tax Office or next to bicycle stands waiting for each other. Space is economically, functionally, spatially and socially important At all proposed places with potential, it has stronger identity at maintaining principles of J. Jacobs theory (Jacobs J., 1961).

Fig.9 Crossroad of Jagiellońska and Kłopotowskiego Streets, proposed by author as new public space in Praga Północ, illustration based on satellite photo Google maps Source: E. Jarecka - Bidzińska

Ryc.9. Skrzyżowanie ulic Jagiellońskiej i Kłopotowskiego, zaproponowane przez autora jako nowa przestrzeń publiczna na Pradze Północ, ilustracja na podstawie zdjęć satelitarnych map Google. Żródło E. Jarecka - Bidzińska

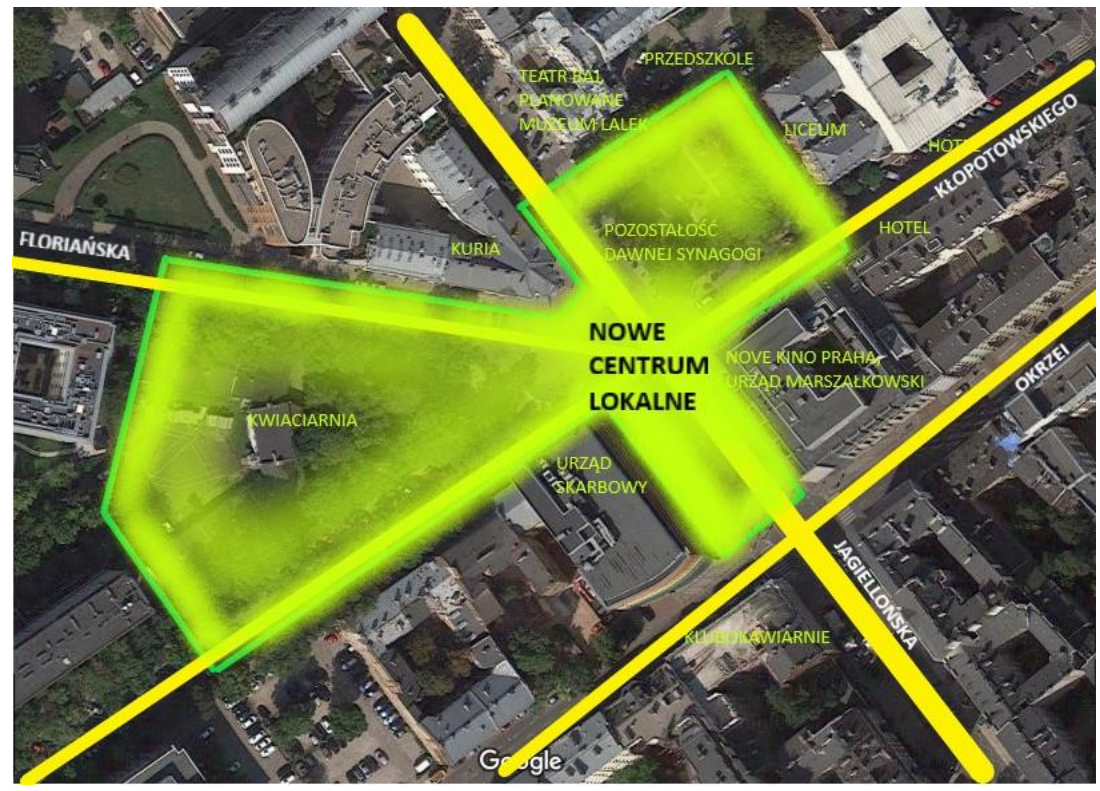

Fig. 10. Results from questionnaires, Is new public space next to Tax Office a good idea? blue color - yes, red - no, orange maybe Source: E. Jarecka Bidzińska

Ryc. 10. Wyniki ankiet, Czy nowa przestrzeń publiczna przy Urzędzie Skarbowym to dobry pomysł? Źródło: E. Jarecka Bidzińska
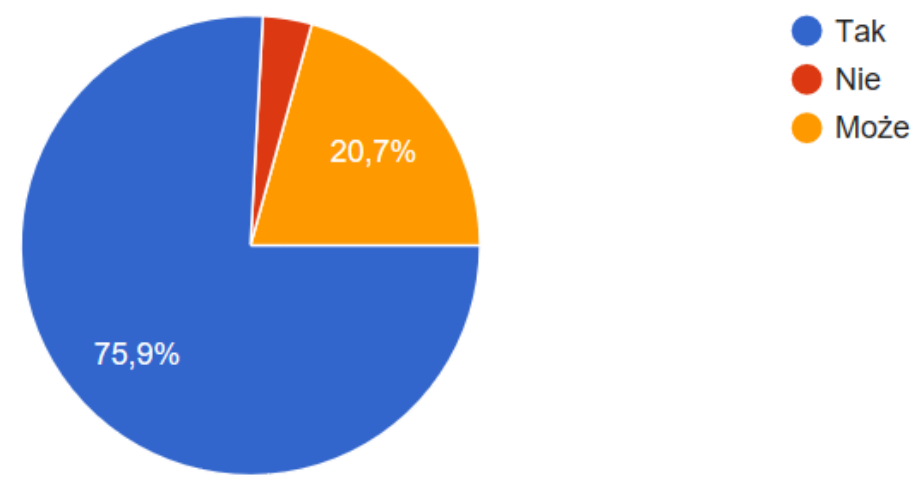

\section{CONCLUSIONS}

It can be concluded that importance of identity in process of shaping new public spaces in Warsaw's Praga - Północ has clearly increased in recent years. There can be many reasons for this state and development trends. One of them is undoubtedly subconscious opposition to global trends and the desire to belong to the local community, giving a sense of mental safety. On the one 
hand cultural heritage, wide range of services, greenery and unique social climate are important factors of development and building economic potential of Praga - Północ, on the other hand developer pressure is a threat to the identity and spatial order of the district.

Place attachment and meaning public spaces of Praga - Północ are: a testimony to history, a place of social integration or cultural and religious events. They create society, provide an evidence of social changes dynamic, symbols of heritage, identity expressions of achievements, aspiration and power of citizens, city planners, leaders and visionaries, scenery of numerous social activities or a place of expression of public opinion. Praga - Północ public spaces identity is building person-toplace bonds, place attachment and meaning. They are essential in process of understanding characteristics of place and considering urban development issues and creating community. Most respondents - over $70 \%$ confirmed need to create new local centers. Praga - Północ is characterized by the lack of clear system of public space connections, which is undoubtedly problem worth further research and development of presented solutions.

\section{SUMMARY}

The case study of identity importance in shaping selected, new urban spaces in Praga - Północ shows how higher level of unique character, heritage, functional and spatial order influence on quality of place attachment and meaning in this district. Respondents in the majority answered that district is reason for their pride and has distinct character. They were also able to indicate attractive public spaces strengthening the sense of identification with Praga - Północ. A positive aspect of the research are opinions of people briefly involved by living or working in Praga - Północ, who were able to indicate the most attractive public spaces they often use. The respondents in selection indicated those places and cultural institutions that have rich history, historic architecture and expressive identity: Bazar Różyckiego, Muzeum Warszawskiej Pragi, Park Praski, Targowa street, Ząbkowska street or Zoological Garden. This shows a strong identity also among group of new social environments in district.

Summing up all these considerations, Praga - Północ is both historical and contemporary district, where cultural heritage and the identity of place meet contemporary requirements, socio-economic, functional, spatial, cultural, city architecture and as well as landscape design. An indispensable factor for success in renewal of current degraded public spaces and shaping a new one is identity of place, which is very strong in Praga - Północ and has reach characteristic. In Praga - Północ there is a high level of identification with the place. The identification with the district is related to public spaces and architecture for more than $70 \%$ of respondents. There are many significant places in Praga - Północ, therefore residents willingly declare a selection of favorite public spaces. Public spaces reflect in the best way character and identity of Praga - Północ.

\section{ZNACZENIE TOŻSAMOŚCI W KSZTALTOWANIU WYBRANYCH, NOWYCH PRZESTRZENI MIEJSKICH W NA PRADZE - PÓŁNOC W WARSZAWIE}

\section{WSTĘP}

Celem artykułu jest studium przypadku miejsc o silnej tożsamości i potencjale do stworzenia atrakcyjnych przestrzeni publicznych: Port Praski (poprzedni port rzeczny, obecna inwestycja komercyjna na terenie 50ha), miejsce pomiędzy Nove Kino Praha (centrum kulturalne) a Urzędem Skarbowym, Centrum Praskie Koneser (dawny kompleks przemysłowy, zaadaptowany na funkcje handlowe), Fort Śliwickiego (obecnie opuszczony) oraz błonia obok dworca Warszawa Stadion Naro- 
dowy. Celem badań jest opisanie znaczenia tożsamości w kształtowaniu wybranych, nowych przestrzeni miejskich na Pradze - Północ oraz przedstawienie wybranych przykładów z systemem powiązań między przestrzeniami publicznymi. Poza charakterystyką aproksymacyjną, znaczenie i status najważniejszych miejsc w Pradze z uwzględnieniem czynników omówionych w sekcji metody. Autor na podstawie danych uzyskanych z ankiet przeprowadzonych w $05.2018 \mathrm{r}$. określa również obszary, które mają potencjał do tworzenia nowych przestrzeni publicznych. Według J. Ghela (Ghel. J.,1987, s.17) Obecność innych ludzi, aktywistów, wydarzeń, inspiracja i stymulacja to jedna z najważniejszych cech przestrzeni publicznych ogółem.

\subsection{Metody badawcze}

1) Empiryczne - poszukiwanie, studiowanie literatury - krytyka jako dyskurs naukowy;

2) Analiza planów, źródeł kartograficznych, opisowych, dokumentacyjnych;

3) Metoda intuicyjna - definicja ogólnych problemów naukowych;

4) Metoda obserwacji;

5) Studium przypadku;

6) Analiza dokumentacji fotograficznej;

7) Wywiady, ankiety (05.2018): eksperci, samorząd lokalny, mieszkańcy;

Dokonano analizy literatury przedmiotu i rozpoczęto dyskurs naukowy. Wnioski z analizy literatury zostały opisane w kolejnych rozdziałach. Przeanalizowano wybrane, najważniejsze, aktualne przestrzenie publiczne oraz miejsca z potencjałem. Uwzględniono następujące czynniki: społeczny, historyczny, kulturowy, dziedzictwo, funkcjonalność, rozwój, lokalizacja, użyteczność publiczna, zieleń, nowoczesność czy architektura. Przeprowadzono wieloletnie obserwacje stanowisk badawczych o różnych porach roku, porze dnia i okolicznościach. Dokumentacja fotograficzna składała się z ponad 300 fotografii przedstawiających różne miejsca, otaczającą architekturę, sposób zagospodarowania oraz sposób użytkowania przestrzeni publicznej. Dokonano wyboru konkretnych obszarów atrakcyjnych przestrzeni publicznych oraz tych wymagających rewitalizacji. Wykonano ankiety wśród władz dzielnic, ekspertów, urzędników, działaczy lokalnych i mieszkańców dotyczące problematyki relacji tożsamości i kształtowania przestrzeni publicznych na Pradze - Północ, opracowane na potrzeby uzyskania opinii publicznej lub opracowania statystycznego. Przeprowadzone badania i wywiady podsumowano w postaci wykresów i tabel.

\section{PRAGA PÓŁNOC - TOŻSAMOŚĆ MIEJSCA}

Genius loci Pragi określa niepowtarzalny charakter, autentyczna struktura tkanki miejskiej, porządek, kompozycja i relacje przestrzenne (Burdzik T, 2012; Jarecka - Bidzińska E., 2016; NorbergSchulz Ch, 1980), historyczna architektura, wielowiekowy tradycyjny rynek, bogata historia, bliskość Starego Miasta, dobra komunikacja miejska z połączeniem z centrum, rezerwat zieleni na brzegu Wisły, bogata oferta usługowa, artystyczne sąsiedztwo, wielokulturowy charakter, społeczność Pragi - jako odrębne środowisko z własną gwarą, wolniejsze tempo czasowe - które tworzą niepowtarzalny klimat miejsca (ryc.1), które przyciąga środowisko artystyczne, inwestorów i turyści. Tożsamość warszawskiej Pragi jest niezwykle złożona i zmienna na przestrzeni wieków, podobnie jak jej historia. (E. Jarecka - Bidzińska 2017).

Pierwsza wzmianka o Pradze w literaturze opisuje samorozwijającą się wieś handlowa w kształcie wrzeciona z 1432 roku. Warszawa nie była wówczas stolicą, ale zyskała znaczenie logistyczne, będąc na skrzyżowaniu szlaków komunikacyjnych i miejscem spotkań Sejmu parlamentu Korony Królestwa Polskiego oraz później Rzeczypospolitej Obojga Narodów (Praca zbiorowa, 2006). Praga była wówczas „funkcjonalnym przedpolem” Warszawy, na którym szlachta z terenów wschodnich mogła odpoczywać przed wjazdem do Warszawy. W 1648 Praga otrzymała prawa miejskie od króla Władysława IV i stała się miastem z przywilejem zakładania cechów rzemieślniczych i kupieckich. Miasto rozwijało się także dzięki szlakom pielgrzymkowym do sanktuarium Matki Bożej Loretańskiej na Pradze. Wiek XVIII to okres świetności Pragi - rozwoju gospodarczego, posiadłości magnackich i szlacheckich (Soltan A, 1998, s.15-41, Kosim I. i J.,1876). 
Praga formalnie stała się częścią stolicy i przestała być samodzielnym miastem w 1791 roku. Insurekcja Kościuszkowska zakończyła kilkadziesiąt lat rozwoju gospodarczego Pragi. „Rzeź Pragi” w 1794 r. zniszczyła dzielnicę, w której wymordowano połowę mieszkańców. Następnie w latach 1807-1811 Napoleon Bonaparte, przygotowując się do wojny z Rosją, polecił wyburzyć zabudowania, by zrobić miejsce dla fortyfikacji. Historyczne śródmieście Pragi przypominało wieś ze zrujnowanymi kościołami, cmentarzami i dworami. W kolejnych latach podjęto próby wprowadzenia planów rozwojowych i naprawczych, ale tylko częściowo wdrożone (pod redakcją Sołtan A, 2009).

Walki na polach Białołęki i Olszynki Grochowskiej odstraszyły ludność od osiedlania się na Pradze. Duża część zabudowy dzielnicy była drewniana, co powodowało pożary i degradację. Wzrosła przestępczość i ubóstwo, a dzielnica zyskała złą reputację. Praga po tym okresie pozostała zaniedbanym przedmieściem rozwijającej się Warszawy. Okres do XIX wieku to nieustanna odbudowa zniszczeń. Druga połowa XIX wieku to rewolucja przemysłowa, pierwsze dworce kolejowe, linie i pierwszy stały most dopiero po 261 latach. Późniejsze znaczne zniszczenia spowodowane były przez ewakuację wojsk rosyjskich po I wojnie światowej, okupacji niemieckiej i stacjonowanie wojsk po wojnie (Elsztain P, 2002).

W okresie międzywojennym nastąpił rozwój Pragi i odbudowa przemysłu. Były też nowe inwestycje publiczne pod przewodnictwem S. Starzyńskiego. Zniszczenia II wojny światowej dotknęły Pragę znacznie mniej niż lewobrzeżne dzielnice Warszawy. Struktura społeczna Pragi zmieniła się z powodu Holokaustu. Do lat 90. XX wieku Praga Północ postrzegana była jako miejsce lokalizacji przemysłu i uciążliwych usług, dzielnica niebezpieczna, zamieszkana z marginesem społecznym. Dziś Praga stała się funkcjonalną częścią centrum miasta.

\section{ISTNIEJACE, HISTORYCZNE PRZESTRZENIE PUBLICZNE, ODNIESIENIE DO HISTORII I ZNACZENIA PRZESTRZENI PUBLICZNYCH W POLITYCE IMPERIUM ROSYJSKIEGO}

Na warszawskiej Pradze - Północ istnieją trzy aktualne, główne, historyczne przestrzenie publiczne: Bazar Różyckiego, Plac Wileński, Plac Weteranów 1863. J. Ghel (Ghel J. Gemzoe,, 2001, s.10) tak opisuje tradycyjne przestrzenie publiczne: przestrzeń publiczna zawsze służyła jako spotkanie miejsce, rynek i przestrzeń ruchu. Bazar Różyckiego to tradycyjny targ z wielowiekową historią. Było to nie tylko miejsce handlu, ale także spotkań towarzyskich i nawet lokalnych nielegalnych biznesów. Bazar Różyckiego miał „złoty wiek” w czasach reżimu sowieckiego, ponieważ był jedynym miejscem z pełną ofertą towarów do sprzedaży i najpopularniejszym miejscem zakupów w całej Warszawie. Bazar powstał w 1901 roku i działa do dziś, choć jego popularność spadła od czasu otwarcia dużego centrum handlowego Dworzec Wileński. Stworzenie targowiska przylegającego do ulicy Targowej, która wcześniej pełniła tę funkcję, umożliwiło na początku XX wieku zorganizowanie handlu, rozwój i stworzenie nieistniejących dziś bulwarów przy głównej ulicy Pragi (ryc.2). Budynki Bazaru Rożyckiego przez ponad 100 lat zachowały w złym stanie technicznym prowizoryczny charakter drewnianych kramów i parterowych pawilonów. Przez wiele lat miejsce to było „sercem” Pragi, jednym z jej symboli i „domem” lokalnego folkloru (Sidorek D, 2009 pp.106130; Sujecki J., 2004). Obok targowiska Centrum Kreatywności i Muzeum Warszawskiej Pragi znajdują się dwie nowe, ważne instytucje kultury. Obecnie Bazar Różyckiego został poddany modernizacji, a stare drewniane pawilony, stoiska i kramy zostały zastąpione nowymi stalowymi wyposażonymi w niezbędne udogodnienia infrastruktury technicznej. Przewidziano też przestrzeń wolną od zabudowy, która ma pełnić funkcję skweru wraz z urządzeniami placu zabaw i podstawową zielenią. Niestety obecne zagospodarowanie ma charakter tymczasowy, a homogeniczna zabudowa jest wykonana $w$ formie pawilonów kontenerowych pozbawionych detalu architektonicznego. W opinii publicznej pojawiają się raczej negatywne oceny, a sam charakter w związku z dużą powierzchnią utwardzoną i stylem architektonicznym jest nazywany „kontenerozo-betonozą” (Wojtczuk, 2021).

Plac Wileński (Plac Wileński) i Plac Weteranów 1863 (Plac Weteranów 1863r.) nawiązują do wizerunku polityki rusyfikacji. Na początku XIX wieku powstały koncepcje urbanistyki Pragi, świadczące o znaczeniu Pragi w okresie Królestwa Kongresowego, w tym pierwszy kompleksowy projekt urbanistyczny Pragi - plan Jakuba Kubickiego (1817). Ten plan, jak również jego późniejsze wersje, nie 
zostały wdrożone. Przewidywały kompozycyjne połączenie z Zamkiem Królewskim, siedem promienistych alei, reprezentacyjne place $z$ budynkami użyteczności publicznej, targowiska, magazyny, place przemysłowe, parkingi i koszary. W 1823 r. wytyczono nowe linie ulic z nazwiskami panujących książąt moskiewskich: Aleksandra, Mikołaja, Konstantyna i Michała. Centralny punkt Pragi został zaprojektowany jako plac na osi nowego mostu i ulicy Aleksandryjskiej, obecnie częściowo zachowany jako Plac Weteranów z 1863 roku. Car chciał stworzyć swoje centrum administracyjne na Pradze. W tym celu zatwierdził nowy projekt regulacji Pragi w 1835 roku. Garnizon, dworce kolejowe i sieć kolejowa znajdowały się na Pradze, co dawało możliwość zdecydowanych działań wojennych i płynnego połączenia z Imperium Rosyjskim. Dla mniejszości prawosławnej wzniesiono cerkiew pw. św. Marii Magdaleny Równej Apostołom. Plac Wileński znajduje się obok tej świątyni, w pobliżu Dworca Wileńskiego, dawniej Dworca Petersburskiego.

\section{KRYTERIA WYBORU I STUDIUM PRZYPADKU MIEJSC Z POTENCJAŁEM NA PRADZE - PÓŁNOC}

Według M. Happach i K. Sadowy (Happach M., Sadowy K., 2014, s.9-20) Centrum Pragi posiada duży i gotowy do uruchomienia potencjał zagospodarowania przestrzennego w postaci sieci ulic i historycznie ukształtowanej zabudowy. Atutem sa nieruchomości będące własnościa miasta, grunty, budynki i usługi w zróżnicowanym stanie, co daje szansę na skuteczną kontrolę przekształceń przestrzennych.

Praga - Północ potrzebuje czytelnego systemu przestrzeni przestrzennych, co przedstawia załączony ryc.3. Ponad $75 \%$ respondentów głosowało za stworzeniem czytelnego modelu przestrzeni publicznych na Pradze - Północ (ryc.4 i 5). Niniejszy artykuł rozwija tę ideę o studium przypadku kilku najbardziej potencjalnych, przyszłych przestrzeni publicznych na Pradze - Północ i ich związku ze znaczeniem tożsamości. Jest kilka aktualnych historycznych przestrzeni publicznych, kilka nowoczesnych i kilka miejsc z potencjałem jak prezentuje Tab. 1. Wyraźne relacje przestrzenne i funkcjonalne będą kształtować harmonijny krajobraz dzielnicy, wspierać tożsamość i dziedzictwo, pozytywnie wpływać na rozwój społeczno-gospodarczy.

Według J. Ghela (Ghel J.,1987, s.51) Przestrzenie publiczne sa potrzebne. Oczywiste jest zapotrzebowanie na wszystkie przestrzenie wszelkiego typu i wszystkich rozmiarów - od małej uliczki mieszkalnej po rynek miejski. Wybrano do porównania różnorodne przestrzenie publiczne: przyszłe bulwary portowe, zaadaptowany dziedziniec Zespołu Dawnych Zakładów Rektyfikacji Spirytusu z historycznymi, neogotyckimi zabytkami, tereny Natura 2000 otoczone zielenia oraz dziedziniec dawnego Fortu zaadaptowany na potrzeby Muzeum Narodowego, Dziedziniec Stadionu z funkcja rekreacyjno-sportowa - najważniejsza przestrzeń publiczna o funkcji eventowej w Warszawie. W nawiązaniu do teorii J. Jacobs (Jacobs J.,1961) wielką wartością Pragi - Północ jest mieszanie nowego ze starym, biednych z bogatymi (...) ta różnorodność jest dobra. W procesie rewitalizacji szczególnie ważne jest wyeliminowanie elementów szkodliwych dla funkcjonowania obszaru, ale jednocześnie zachowanie specyfiki, przeciwdziałanie gentryfikacji i zapobieganie degradacji zabytków (Bartoszewicz D., 2009).

\section{WYBRANE PRZESTRZENIE PUBLICZNE NA PRADZE - PÓŁNOC}

Nowe przestrzenie publiczne kreują społeczeństwo, ale także aktywizują ogromny potencjał dzięki rewitalizacji terenów poprzemysłowych, które mogą rozwiązać część problemów gospodarczych i społecznych na Pradze - Północ. Podstawowym problemem jest to, aby przestrzenie te dawały możliwość integracji społecznej, były odpowiedzią na potrzeby mieszkańców, uprzywilejowany ruch pieszy, różnorodna funkcja i architektura. Aby rozważyć zasadność powyższego wyboru należy dokładnie przeanalizować istniejące, historyczne przestrzenie publiczne, ich zalety i wady. Z istniejących przestrzeni publicznych omówionych w poprzednim rozdziale, atrakcyjny jest jedynie Plac Weteranów z 1863 roku. Znajduje się tam kościół i szpital, które generują tłum przechodniów w przestrzeni placu. Są tam: mała architektura, ławki, pomniki, sąsiedztwo zabytkowej architektury, zieleń, oryginalne brukowane uliczne i uliczne latarnie. Na placu lub w jego bezpośrednim sąsiedz- 
twie znajdują się również: popularny bar mleczny, orientalna restauracja, sklep spożywczy, biuro paszportowe, fotograf, mały market oraz hotel. Wszystko to tworzy charakter i warunki sprzyjające dobrowolnemu korzystaniu z placu.

Plac Wileński jest zawsze pusty pomimo nowej nawierzchni, znajdującego się tam wejścia do metra i zieleni. Gdzie jest problem? Przede wszystkim jest to ogromny węzeł komunikacyjny - nikt nie chce spędzać czasu w jego bezpośrednim sąsiedztwie. Dodatkowo pobliska Galeria Wileńska skupia ruch pieszy związany z transportem i handlem. W związku z tym w pobliżu nie ma bezpośredniego dostępu do drobnego handlu czy gastronomii. Ponadto znajdują się tu również nieruchomości zamknięte dla ruchu pieszego: Budynek Dyrekcji Kolei, zabudowania parafii prawosławnych oraz dawna administracja.

Nową, ale nieistniejącą przestrzenią publiczną, którą w sondażu wybrała większość respondentów, jest regionalna inwestycja Port Praski (ryc.6). Cały teren to ok. 50 ha, z czego część jest rezerwatem ze względu na istniejącą zieleń naturalną, część przeznaczona jest pod budynki biurowe, a część pod usługi. Obecnie teren w bezpośrednim sąsiedztwie starego portu rzecznego jest już częściowo zabudowany. Inwestycją poprzedzającą zabudowę w bezpośrednim sąsiedztwie kanałów była budowa śluzy chroniącej przed powodzią i regulującej poziom wody w przyszłej marinie. $\mathrm{Na}$ terenie portu nie zachowała się historyczna architektura. Projekt obejmuje wykonanie promenady portowej z usługami na parterach oraz rewitalizację terenów poprzemysłowych. Jest to jednak inwestycja w pełni komercyjna, w której różnorodność architektury i funkcji może nie wpisywać się we wszystkie potrzeby lokalnych mieszkańców. W pobliżu portu rzecznego znajduje się otoczenie zabytkowej, XIX-wiecznej architektury Starej Pragi, która przetrwała II wojnę światową i jest świadectwem czasu.

Kolejną przestrzenią wybieraną przez respondentów na drugim miejscu jest teren dawnego opuszczonego fortu wojskowego. Jest to teren wybrany przez samorząd gminy pod nową inwestycję Narodowe Muzeum Przyrody w adaptowanych obiektach zabytkowych oraz kompleks nowej architektury (ryc.7). Cały teren sąsiaduje z obszarami Natura 2000, terenami zielonymi oraz stadniną koni. W pobliżu znajdują się nowe osiedla mieszkalne o wysokich walorach architektonicznych oraz mniej estetyczne, wysokie osiedla mieszkaniowe z lat 80. XX wieku. Problemem tego obszaru jest defragmentacja przestrzeni, gdzie współczesna zabudowa mieszkaniowa drastycznie zaburza urbanistykę i wprowadza nieporządek przestrzenny w zabudowę historyczną: fort, kaponiery, koszary. Ponadto jest to obszar z licznymi barierami miejskimi: linia kolejowa, nasyp, rzeka Wisła, wielopasmowa arteria Jagiellońska, ogromny węzeł komunikacyjny - Rondo Starzyńskiego. Wartością jest zieleń, zabytkowa zabudowa oraz puste tereny pod inwestycje. Byłoby to ożywienie niepopularnego terenu i stworzenie miejsc pracy w ramach inwestycji publicznej, co pozwala samorządowi kontrolować poziom ochrony otaczającej przyrody i odpowiednią adaptację zabytkowej architektury w procesie inwestycyjnym.

Ostatnim omawianym miejscem będzie teren przy Urzędzie Skarbowym (ryc.8,9, 10). Jest to istniejący plac, który przy niewielkich nakładach finansowych, mógłby stać się nowym centrum Pragi. Potrzebna jest tylko inna organizacja ruchu kołowego lub plac z dostępem tylko dla pieszych. Miejsce spełnia wszystkie wymagania omówione przez J. Jacobs: różnorodność architektury, zabudowa historyczna i współczesna, mieszanka funkcji (kino, biura, kawiarnie, sklepy, galerie, instytucje katolickie, inne instytucje publiczne i usługi prywatne). (J. Jacobs, 1961) Dobra komunikacja z pobliską stacją metra. Plac znajduje się w sercu dzielnicy i miejscu spotkań. Mieszkańcy często siedzą na parapetach Urzędu Skarbowego lub czekają na siebie przy stojakach rowerowych. Przestrzeń jest ważna ekonomicznie, funkcjonalnie, przestrzennie i społecznie. We wszystkich proponowanych miejscach z potencjałem ma silniejszą tożsamość przy zachowaniu zasad teorii J. Jacobs. (J. Jacobs, 1961)

\section{KONKLUZJE}

Można stwierdzić, że znaczenie tożsamości w procesie kształtowania nowych przestrzeni publicznych na warszawskiej Pradze - Północ wyraźnie wzrosło w ostatnich latach. Przyczyn takiego stanu i trendów rozwojowych może być wiele. Jednym z nich jest niewątpliwie podświadomy sprzeciw 
wobec światowych trendów oraz chęć przynależności do lokalnej społeczności, dająca poczucie bezpieczeństwa psychicznego. Z jednej strony dziedzictwo kulturowe, szeroka oferta usług, zieleń i unikalny klimat społeczny są ważnymi czynnikami rozwoju i budowania potencjału gospodarczego Pragi-Północ, z drugiej strony presja deweloperska stanowi zagrożenie dla tożsamości i ładu przestrzennego dzielnicy.

Przywiązanie i znaczenie społeczne przestrzeni publicznych Pragi - Północ to: świadectwo historii, miejsca integracji społecznej, wydarzeń kulturalnych i religijnych. To one tworzą społeczeństwo, świadczą o dynamice przemian społecznych, symbolach dziedzictwa, tożsamościowych wyrazach dokonań, aspiracji i potędze mieszkańców, urbanistów, liderów i wizjonerów, scenerii licznych działań społecznych czy przestrzeni wyrażania opinii publicznej. Tożsamość przestrzeni publicznych Praga - Północ to budowanie więzi międzyludzkich, przywiązania do miejsca i znaczenia. Są niezbędne w procesie rozumienia specyfiki miejsca oraz rozważania zagadnień związanych z rozwojem miast i tworzeniem społeczności. Większość respondentów - ponad 70\% potwierdziło potrzebę tworzenia nowych centrów lokalnych. Praga - Północ charakteryzuje się brakiem klarownego systemu powiązań przestrzeni publicznej, co jest niewątpliwie problemem wartym dalszych badań i rozwoju prezentowanych rozwiązań.

\section{PODSUMOWANIE}

Studium przypadku znaczenia tożsamości w kształtowaniu wybranych, nowych przestrzeni miejskich na Pradze - Północ pokazuje, jak wyższy poziom unikatowości, dziedzictwa, ładu funkcjonalnego i przestrzennego wpływa na jakość przywiązania oraz znaczenie miejsca w tej dzielnicy. Respondenci w większości odpowiedzieli, że dzielnica jest powodem ich dumy i ma odrębny charakter. Udało im się również wskazać atrakcyjne przestrzenie publiczne wzmacniające poczucie identyfikacji z Pragą - Północ. Pozytywnym aspektem badania są opinie osób krótko związanych z życiem lub pracą na Pradze - Północ, które potrafiły wskazać najatrakcyjniejsze przestrzenie publiczne, z których często korzystają. Wyselekcjonowani respondenci wskazali te miejsca i instytucje kultury, które mają bogatą historię, zabytkową architekturę i wyrazistą tożsamość: Bazar Różyckiego, Muzeum Warszawskiej Pragi, Park Praski, Targową, Ząbkowską czy Ogród Zoologiczny. Świadczy to o silnej tożsamości również wśród grupy nowych środowisk społecznych w dzielnicy.

Podsumowując wszystkie te rozważania, Praga - Północ to zarówno historyczna, jak i współczesna dzielnica, gdzie dziedzictwo kulturowe i tożsamość miejsca spełniają współczesne wymagania, społeczno-gospodarcze, funkcjonalne, przestrzenne, kulturowe, urbanistyczne, a także krajobrazowe. Niezbędnym czynnikiem sukcesu w odnowie dotychczasowych zdegradowanych przestrzeni publicznych i kształtowaniu nowej jest tożsamość miejsca, która na Pradze - Północ jest bardzo silna i ma charakterystyczny zasięg. Na Pradze-Północ panuje wysoki stopień identyfikacji z miejscem. Identyfikacja z dzielnicą związana jest z przestrzeniami publicznymi i architekturą dla ponad $70 \%$ respondentów. Na Pradze-Północ jest wiele znaczących miejsc, dlatego mieszkańcy chętnie deklarują wybór swoich ulubionych przestrzeni publicznych. Przestrzenie publiczne najlepiej odzwierciedlają charakter i tożsamość Pragi - Północ.

\section{BIBLIOGRAPHY}

Bartoszewicz D., 2009, Rewitalizacja warszawskiej Pragi: przekształcanie zdegradowanej przestrzeni wielkomiejskiej w oparciu o lokalne dziedzictwo kulturowe, Instytut Gospodarki Przestrzennej i Mieszkalnictwa,

Burdzik T. 2012, Przestrzeń jako składnik tożsamości w świecie globalizacji, „Kultura - Historia - Globalizacja” Elsztain P., 2002, Moja Praga, Dom Wydawniczy Syrenka, Warszawa

Gehl J., 1970/1987. Life between buildings: Using public space. New York, Van Nostrand Reinhold

Gehl J., Gemzoe L. , 2001, New city spaces, Kopenhaga, Danish Architectural Press, p.10

Happach M., Sadowy K., 2014, Architektura dla społeczności lokalnych - przestrzenie wspólne Pragi Północ,

Ursynowa i Wilanowa, Kwartalnik Naukowy Uczelni Vistula 2017, 4(54), pp.9-20

Jacobs J. ,1961, The Death and Life of Great American Cities, Random House 
Jarecka - Bidzińska E.,2016, Genius loci Pragi jako katalizator odrodzenia kultury miejsca, Zeszyty Naukowe Akademi Finansów i Biznesu Vistula, 2016, 159.

Jarecka - Bidzińska E.,2017, Warszawska Praga - Szukanie Tożsamości, Zeszty Naukowe AFiB Vistula 53(2) 2017

Kosim I. i J., Fritza Wernicka opis Warszawy z 1876 roku (tłumaczenie i opracowanie) (Fritz Wernickes Beschreibung Warschaus aus den Jahre 1876 (Übersetzung und Bearbeitung), [w:] Warszawa XIX wieku, Rozdz. 2, S. 322

Mikroprogram Rewitalizacji Dzielnicy Praga-Północ, 2012, Urząd Miasta Stołecznego Warszawy - Dzielnica Praga Północ

Norberg-Schultz C., 1980, Genius Loci - Spirit of Place [in:] Architectural Design, 7-8, pp. 85-88.

Pod redakcją Sołtana A., 2009, Odkrywanie Warszawskiej Pragi, Fundacja Hereditas, , Warszawa.

Praca zbiorowa, 2006, Warszawskiej Pragi dzieje dawne i nowsze, Jeden Świat, Warszawa

Sidorek D.,2009, Bazar Różyckiego, Konteksty. Polska Sztuka Ludowa 01-02, pp.106-130

Sołtan A., 1998, Prawobrzeżna Warszawa w przewodnikach po mieście (XIX-XX w.), Kronika Warszawy, s. 15-41 ISSN 0137-3099, nr 1-4(103-106)/1998

Sujecki J., 2004, Historia Bazaru Różyckiego, Kronika Warszawy, nr 1/2004

Wojtczuk M., Nowy bazar Różyckiego nabiera kształtów. Ale czy te pawilony spodobają się warszawiakom?, Gazeta Wyborcza, źródło: Nowy bazar Różyckiego w Warszawie. Czy pawilony spodobają się warszawiakom? (wyborcza.pl) [dostęp/access 2021.07.08]

Organization Project for Public Spaces (NGO), https://www.pps.org/about/ [dostęp/access 2021.07.08]

\section{AUTHOR'S NOTE}

Ewa Jarecka - Bidzińska: Architect, urban planner with a phd in technical sciences in the discipline of architecture and urban planning. Head of postgraduate studies in Spatial Economy in Practice at the Faculty of Geodesy and Cartography of the Warsaw University of Technology. A specialist in the field of spatial planning, urban and architectural design.

Małgorzata Denis: Research interest transformations of cities, public spaces, spatial planning, changes in the functional-spatial structure occurring in cities. Faculty of Geodesy and Cartography, Department of Spatial Management and Environmental Sciences

\section{O AUTORZE}

Ewa Jarecka - Bidzińska: Architekt, urbanista z tytułem doktora nauk technicznych w dyscyplinie architektura i urbanistyka. Kierownik studiów podyplomowych Gospodarka Przestrzenna w praktyce na Wydziale Geodezji i Kartografii Politechniki Warszawskiej. Specjalista w obszarze planowania przestrzennego, projektowania urbanistycznego i architektonicznego.

Małgorzata Denis: Zainteresowania badawcze: Przeobrażenia zachodzące w miastach, przestrzenie publiczne, planowanie przestrzenne, zmiany struktury funkcjonalno - przestrzennej, jakim podlegają miasta. Wydział Geodezji i Kartografii, Katedra Gospodarki Przestrzennej i Nauk o Środowisku Przyrodniczym.

Contact | Kontakt: ewa.bidzinska@pw.edu.pl; malgorzata.denis@pw.edu.pl 